\title{
遷移金属触媒を用いる共役アレンの新しい付加環化反応
}

\author{
村 上 正 浩*・伊 丹 健一郎*·生 方 実* \\ 辻到*・伊 藤 嘉 彦*
}

\section{New Cycloaddition Reactions of Conjugated Allenes Catalyzed by Transition Metal Complexes}

\author{
Masahiro Murakami*, Kenichiro Itami*, Minoru Ubukata* \\ Itaru TsujI*, Yoshihiko ITo*
}

\begin{abstract}
Development of new cycloaddition reactions of conjugated allenes catalyzed by transition metal complexes is described. In the first place, the synthesis and structures of vinylallene-rhodium complexes were investigated. (Vinylallene)rhodium complexes of three kinds of coordination modes, that is, $\eta^{2}$-coordination, $\eta^{4}$-coordination, and planar $\sigma^{2}$-coordination, were selectively synthesized by facile ligand substitution of the Wilkinson's complex with vinylallenes of different substitution patterns. The endo-exo isomerization observed with the $\eta^{4}$-complex suggested a considerable contribution from the metallacyclic form. This structural study led us to develop a new carbonylative $[4+1]$ cycloaddition reaction of vinylallenes, which was further extended to a highly enantioselective synthesis of 2(alkylidene)cyclopentenone. Next, the intermolecular directed $[4+2]$ cycloaddition of a vinylallene with an ordinary 1,3-diene was achieved by the use of a palladium (0) catalyst. An excellent specificity observed between the vinylallene geometries and the cycloadduct stereostructures was explained by assuming a mechanism involving a ( $\pi$-allyl) palladium intermediate. The iridium-catalyzed carbonylative $[5+1]$ cycloaddition reaction was also developed, wherein a six-membered cyclohexenone skeleton was assembled from allenylcyclopropane and carbon monoxide.
\end{abstract}

Key words : $[4+1]$ Cycloaddition, $[4+2]$ Cycloaddition, $[5+1]$ Cycloaddition, Vinylallene, Allenylcyclopropane, Rhodium, Iridium, Palladium, $\eta^{2}$-Coordination, $\eta^{4}$-Coordination, Planar $\sigma^{2}$-coordination, Metallacycle, Carbonylation, Asymmetric synthesis, Diels-Alder reaction

\section{1.はじめに}

Diels-Alder 反応に代表される付加環化反応は, 複雑 な構造の環状化合物を一挙に，しかも立体選択的に組み 上げる極めて強力な合成手法である(十字路参照) ${ }^{1)}$ 。 熱・光・ルイス酸などが, そのプロモーターとして古く からよく知られている。一方近年になり遷移金属触媒を 用いる例が注目されている2)。とりわけ，電子を押し引

* 京都大学大学院工学研究科合成 - 生物化学専攻 (

* Department of Synthetic Chemistry and Biological Chemistry, Graduate School of Engineering, Kyoto University
きするへテロ原子官能基を持たない不活性な基質に対し ても有効に働くことを特徴とする。また，他のプロモー ターでは不可能な付加環化様式を実現することあでき る。その反応の概略を, $[2+2]$ 型主 1 の応を例にとって 次に示す。付加環化反応に加わる基質は, 一般に炭素一 炭素多重結合などの不飽和基を持っているが，まずそれ らの基質が遷移金属に配位し活性化される。次に，基質 間で炭素－炭素結合の生成が起こる。還元的脱離によ り, 付加環化生成物が金属の配位圈から離れる。同時に, 新たな基質の配位が可能な遷移金属錯体が再生され，そ れが次の触媒サイクルを駆動する。すなわち遷移金属 は，基質を自らの配位圈に正しく配列させたうえで活性 化する鋳型(テンプレート)として働く。

济 本稿での $[\mathrm{m}+\mathrm{n}]$ 付加環化という表記は，環構成成分の原子数を表す。 


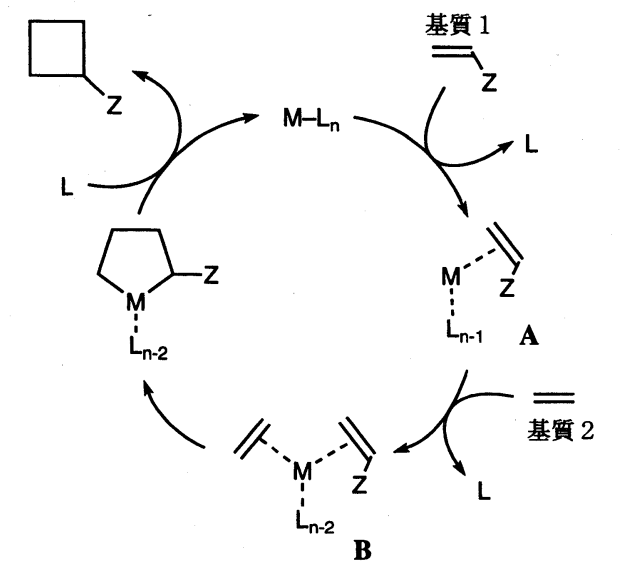

このような遷移金属錯体触媒による付加環化反応で は，基質と遷移金属が形成する配位錯体 A あるいは $\mathrm{B}$ に相当するすのが鍵中間体となる場合が多い。筆者らは 基質として共役アレンを取り上げ，これと遷移金属の錯 体の構造について興味をもって研究を開始した。得られ た共役アレンの錯体を付加環化反応における鍵中間体と 見立てることにより，新しい触媒的付加環化反応を開発 することができたので，本稿ではその展開について紹介 する。

\section{2. ビニルアレンーロジウム錯体の合成と構造}

ブタジェンなどの 1,3-ジェンは遷移金属の典型的な $\pi$ 性の 4 電子供与配位子であり, ジェン一遷移金属錯体 の構造や反応性については古くから活発な研究が行われ てきた。その主な配位様式を次に挙げる。

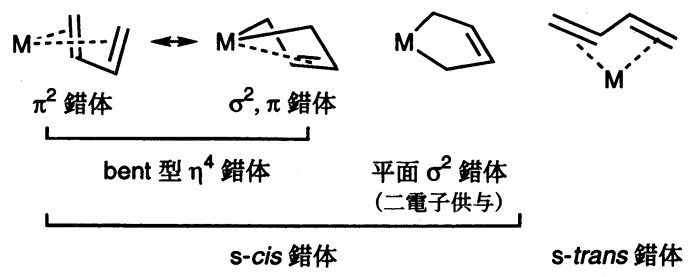

一方，通常のジェンに集積二重結合を付加したビニル アレンの遷移金属錯体については, 僅かに $\eta^{4}$ 配位の鉄 カルボニル錯体が数例報告されているに過ぎない3)。筆 者らは独自のビニルアレンの合成経路を持っていたこ (4)からその配位様式に興味を持ち，まずロジウム錯体 の合成に着手した。その結果, 置換基の異なる三種類の ビニルアレンから，それぞれ配位様式の異なる錯体を合 成することができた ${ }^{5)}$ 。まずアレン末端に置換基を持た
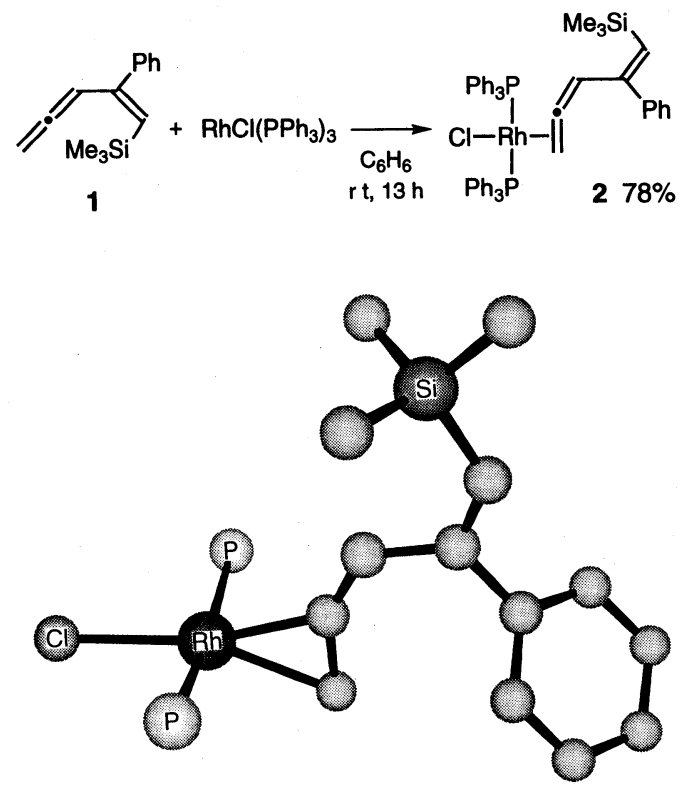

Fig.1 Molecular structure of 2 [the phenyl groups on the phosphorus atoms and the hydrogen atoms omitted for clarity].

ないビニルアレン(1)に Wilkinson 錯体を作用させたと ころ, 塩素原子のトランス位の $\mathrm{PPh}_{3}$ がアレンの末端二 重結合で置換された平面四配位型の $\pi$ 錯体(2)を与えた （図 1)。この場合，ビニルアレンは単純なアレンと同じ 配位挙動)を示したことになる。

次に, アレンの末端炭素が二つのメチル基で置換され たビニルアレン(3)を用いたところ，今度は二分子の $\mathrm{PPh}_{3}$ 配位子が置換され， $\eta^{4}$ 錯体(4)を異性体混合物とし て与えた。それぞれの単結晶の X 線構造解析により, 出 発ビニルアレンのビニル部分の $E$ 配置を保持した endo 体と, $Z$ 配置に異性化した exo 体と判明した(図 2)。ビ ニルアレン(1)の場合とは異なり置換ビニルアレン(3)か ら $\eta^{4}$ 錯体が得られたのは, アレン末端の立体障害の増 加によるあのと考えられる。
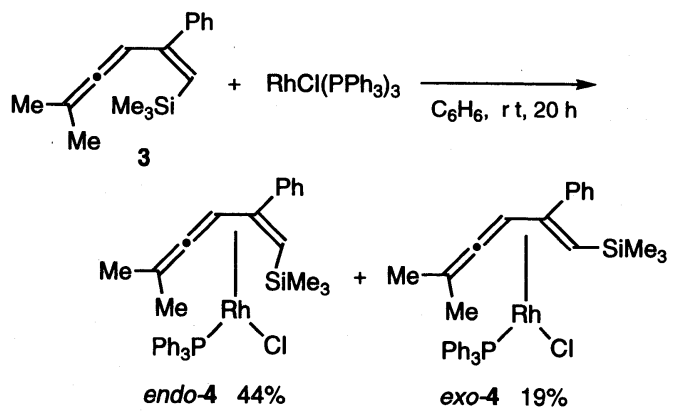

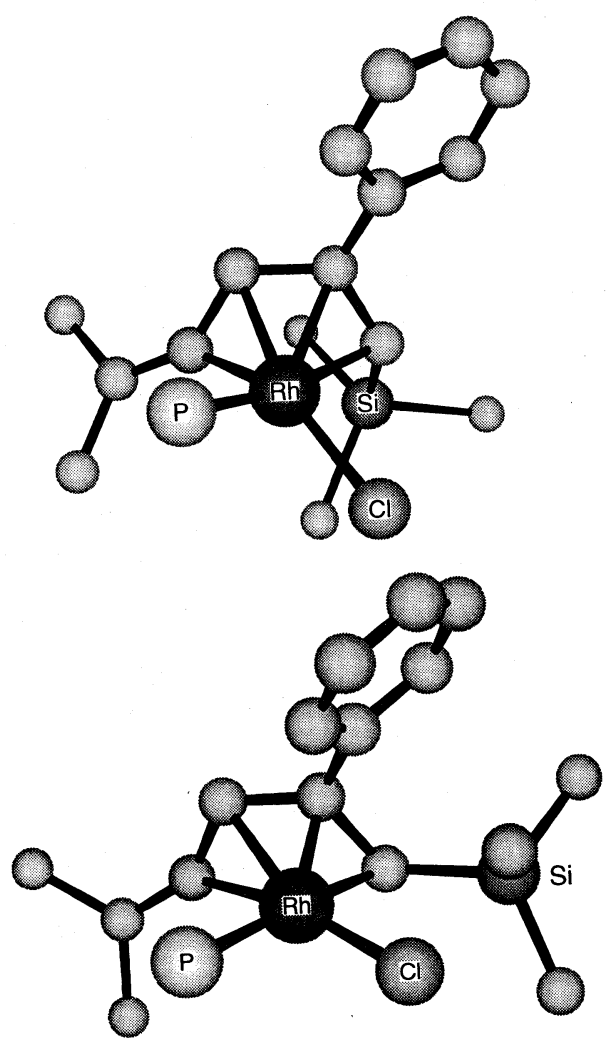

Fig. 2 Molecular structures of endo-4 (top) and exo4 (bottom) [the phenyl groups on the phosphorus atoms and the hydrogen atoms omitted for clarity].

興味深いことに, 単離した endo-4を加熱すると, 徐々にexo-4 へと異性化した。この異性化は, 平面型 $\sigma^{2}$ 配位錯体を中間に経由する “flip-envelope" 機構で進行

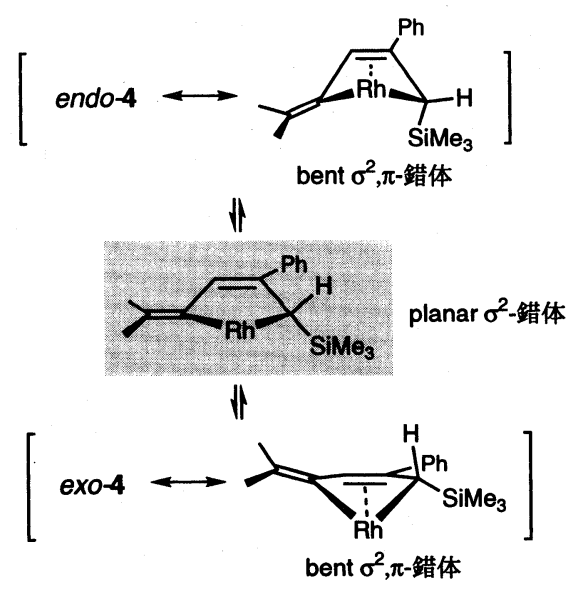

The ligands on rhodium are omitted for clarity.
するあのと考えられる。

$\eta^{4}$ ジェン錯体の endo-exo 異性化はしばしばみられ る7)。しかし, 中間に経由すると想定されている平面型 $\sigma^{2}$ 配位ジェン錯体を単離・構造決定した例は少ない8)。 筆者らは 1 および 3 に続いて, ビニル末端に置換基を持 たないビニルアレン(5)を用いて Wilkinson 錯体との反 応を行った。この場合は一分子の $\mathrm{PPh}_{3}$ 配位子のみの置 換が起こり，ビニルアレンが完全に平面 $\sigma^{2}$ 配位した五 配位錯体 6 を得ることができた(図 3) ${ }^{5 b}$ )。錯体 6 では,

$\mathrm{C} 5$ 位に置換基がないために立体的に嵩高い $\mathrm{PPh}_{3}$ が 2 分子中心金属にトランス配位することができ，これに よってメタラシクロペンテン骨格の環内炭素－炭素二重 結合(C3-C4)がロジゥムに配位することなく，平面型 $\sigma^{2}$ 配位構造を取っているあのと解釈できる。また単結晶の 構造には次のような特徵がみられた。すなわち, $\mathrm{C} 1-\mathrm{C} 2-$ C3-C4 のジェン系は同一平面上にあり (二面角 $179.2^{\circ}$ ), C2-C3 間の単結合 $(1.452(6) \AA)$ は C4-C5 単結合 (1.510 (5) $)$ 上り著しく短い。また環外炭素－炭素二重結合 C1-C2 (1.362 (6) §) は, $\eta^{4}$ 錯体の対応する結合 (endo-4

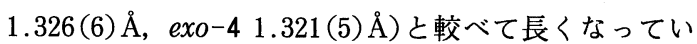
る。これらの結果は, C1-C2-C3-C4 からなるジェン骨格 の強い共役相互作用を示唆する。この共役安定化効果
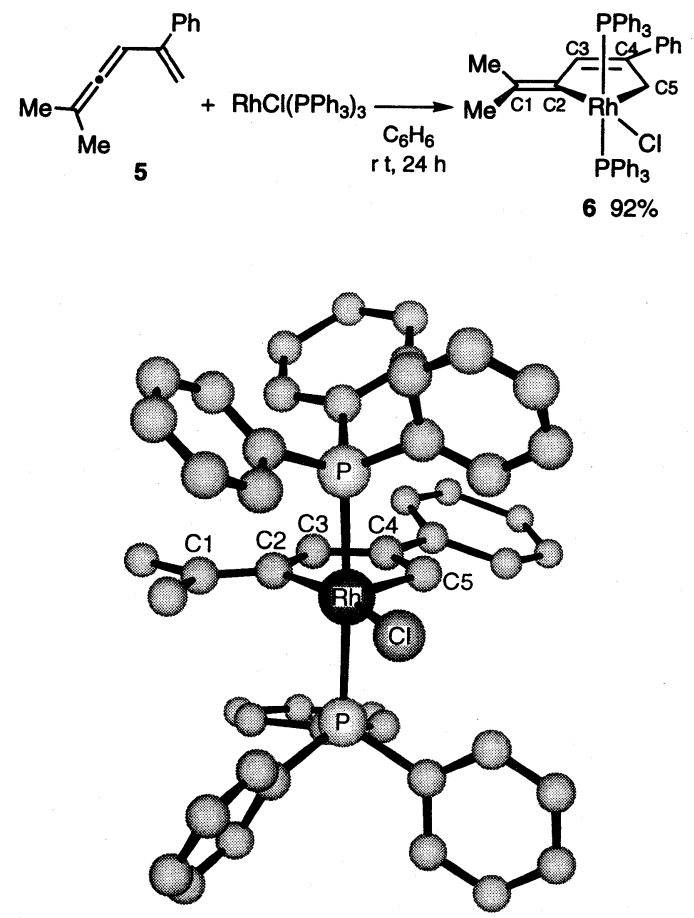

Fig.3 Molecular structure of 6 [the hydrogen atoms omitted for clarity]. 
は，ビニルアレン錯体が通常のジエン錯体ではほとんど 見られない平面型 $\sigma^{2}$ 配位を指向する要因の一つ之考え られる。

上記のようにビニルアレン配位子の置換基を変化させ ることにより，ロジゥム錯体の三種類の配位様式を制御 することができた。ビニルアレンの簡便な合成経路を確 立していたことが, これらの錯体の選択的合成を可能に した。

\section{3. ビニルアレンーロジウム錯体と一酸化炭素の} 反応一そしてその触媒化

次に筆者らは, ビニルアレンーロジウム錯体の構造に 関して得た基礎的知見を, 有機合成反応の開発に活用す ることを目指した。まず, $\eta^{4}$-ビニルアレン錯体で endoexo 異性化が容易に起こることから, bent型メタラサイ クル (bent $\sigma^{2}-\pi$ 配位)構造の寄与が，通常のジェン錯体 の場合と比較して大きいと予想した。この性質は, 置換 基を選べば平面 $\sigma^{2}$ 配位錯体の単離すら可能であること からあ支持される。従って，ビニルアレン錯体における 炭素一金属結合は， $\sigma$ 結合性がかなり増している。極言 すると，ビニルアレンが錯体形成により $\pi$ 結合性の配位 子から $\sigma$ 結合性の配位子へ移行している。この仮説が正 しければ，炭素一金属 $\sigma$ 結合に特有である不飽和有機化 合物 (一酸化炭素, 炭素一炭素多重結合種など)の㨂入が 起こりやすくなっていると考え，まず一酸化炭素との反 応性から検討した。 $\eta^{4}$ 錯体 $($ endo-4) に一酸化炭素を常圧 で作用させたところ，期待したように $[4+1]$ 付加環化反 応が容易に進行し、シクロペンテノンをほぼ定量的に与 えた。メタラサイクルの $\mathrm{C}-\mathrm{Rh}$ 結合に一酸化炭素が挿 入後, 還元的脱離したあのと思われる。これに対し, $\pi$ 錯 体 2 は付加環化生成物を全く与えなかった。

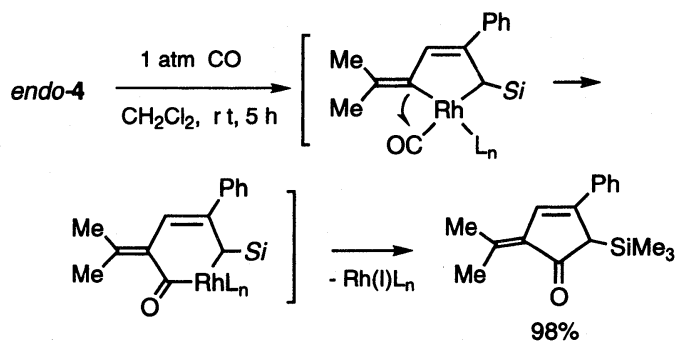

次に, このカルボニル化反応の触媒化を目的として条 件を検討した。その結果，オートクレーブ中一酸化炭素 圧の下でカチオン性の $\mathrm{Rh}$ ( I ) 錯体を用いれば, 各種ビ ニルアレンの $[4+1]$ 付加環化反応が触媒的に進行し, 対 応するシクロペンテノンを高収率で与えることがわかっ

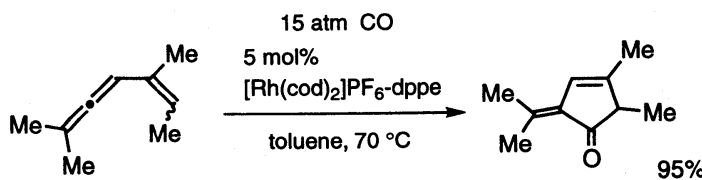

た。代表例を上に示す。

このようにビニルアレンーロジゥム錯体に関する構造 的知見を基に, ビニルアレンの新しい $[4+1]$ 付加環化反 応帛を開発することができた。

\section{4. ビニルアレンの不斉 $[4+1]$ 付加環化反応}

次に不斉触媒反応化を試みた。すなわち, ロジゥムの 配位子として光学活性ホスフィンを用いてビニルアレン の $[4+1]$ 付加環化反応を行い, 生成物の 5 位への不斉誘 起について調べた。各種のキレート性の光学活性二座ホ スフィン配位子を試したところ，Burk らが開発した DuPHOS 配位子 ${ }^{10)}$ が最むよい結果を与えることがわ かった。一般に不斉誘導が困難とされる配位性のへテロ 原子官能基を全く持たない基質の場合であ，比較的よい エナンチオ選択性がみられた ${ }^{11)} 。$

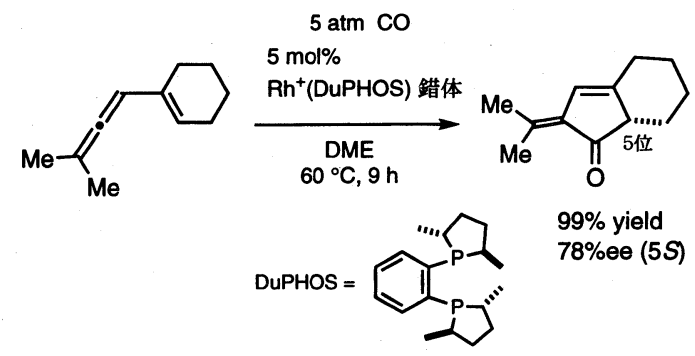

また，エステル置換基を持つ基質ではより低温で反応 が進行するため, カルボニル化反応としては極めて高い エナンチオ選択性( $95 \%$ ee)が得られた。

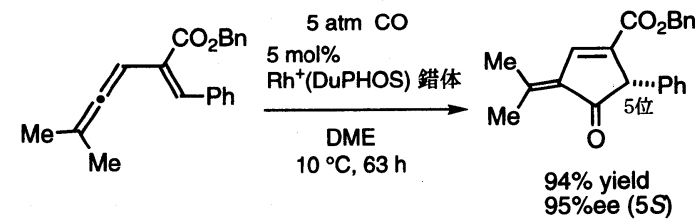

観察されたエナンチオ選択性は, 次に示す $\eta^{4}$ 配位の モデルを仮定することにより説明できる。モデルIで は，ホスホラン環上のメチル基とビニル位置換基 $\mathrm{R}^{2}$ と の間，およびあう一方のホスホラン環上のメチル基とア レン末端のメチル基間にそれぞれ立体反発がある。一方 モデル II では，このような反発がないためビニルアレ ンが不斉環境にうまくフィットする。従って，モデル II 
モデル I disfavored
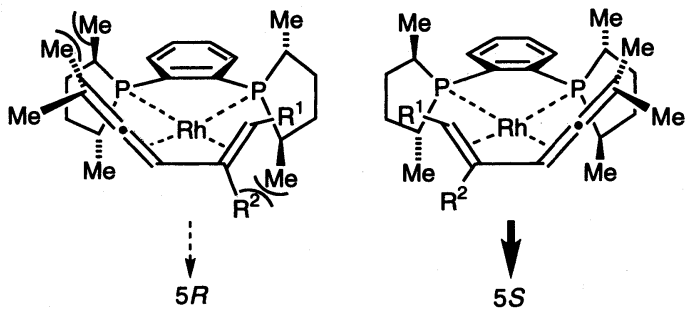

の形の配位を経て $5 S$ 体が生成する。

ここまで述べてきたビニルアレンーロジゥム錯体の構 造に関する研究加ら不斉 $[4+1]$ 付加環化反応への展開 は，錯体触媒による合成反応の開発から始まり，次に有 機金属錯体を用いて機構を解明するという従来型のアプ ローチとは逆に進んだ点で興味深い。

\section{5. ビニルアレンの $[4+2]$ 付加環化反応}

[4+2]付加環化反応は，Diels-Alder 反応としてよく 知られ，特にエナンチオ選択性までも含めた各種の立体 選択性が得られるため, 最む沉用されている付加環化反 応となっている。しかし，一般にカルボニル基やエーテ ル置換基などでジェノフィルあるいはジェンを電子的に 活性化することが必要である。一方, そのようなへテロ 原子官能基を持たない不活性な基質間の $[4+2]$ 付加環化 反応は困難とされていた。最近，遷移金属触媒を用いて この問題を解決した例が報告されている ${ }^{12)}$ 。筆者らは, 前節で述べたビニルアレンの $[4+1]$ 付加環化反応をさら に [4+2]型反応へと展開し, 不活性な基質間の立体特異 的な交差 $[4+2]$ 付加環化反応を初めて開発した ${ }^{13)}$ 。すな わち, パラジゥム $(0)$ 触媒の存在下でビニルアレンにブ タジェン(約 10 当量)を作用させると, 6 員環生成物 8 が
高収率で得られた。ビニルアレンが基質選択的に四炭素 ユニットを供与して，他方ブタジェンはジェノフィルと して働いたことになる。ブタジェンに由来するビニル基 は位置選択的に 4 位に導入される。この選択性は, 安定 な $\pi$ アリルパラジゥム錯体を経る機構を仮定すること により説明することができる。まず，ビニルアレンとパ ラジゥムが bent 型 palladacycleをつくり, 次に $s$ trans 型で配位したブタジェンとの間で次式に示すよう な形で炭素一炭素結合を生成し， $\pi$ アリルパラジゥム 7 を与える。最後にシクロへキセン骨格が還元的脱離す る。一方, ブタジェンの代わりに通常のオレフィンを用 いると, 交差 $[4+2]$ 付加環化反応が全く進行しない。こ のことから， $\pi$ アリルパラジゥム中間体の生成が上記の 不活性基質間の $[4+2]$ 付加環化反応の重要な推進力之 なっているあのと考えられる。

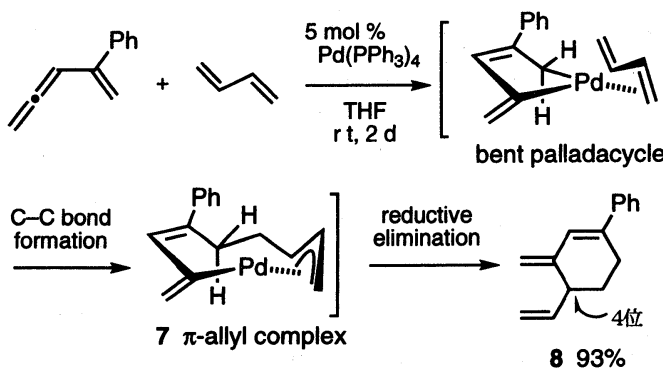

さらに興味深いことに，ビニル基部分の立体配置の異 なるビニルアレン $(Z)-9$ と $(E)-9$ を基質として用いたと ころ, それぞれの生成物の立体構造との間に極めて高い 特異性がみられた。すなわち，(Z)-9 からはcis-11 のみ が，また $(E)-9$ からはtrans-11 のみがそれぞれ得られ た。この立体特異性は，いずれのビニルアレンから出発

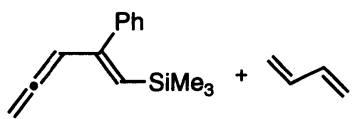

(Z)-9

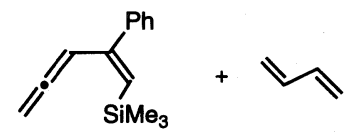

(E)-9

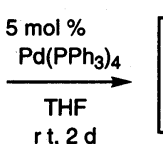

$r \mathrm{t}, 2 \mathrm{~d}$

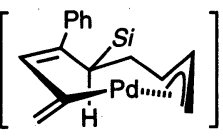

$10 \pi$-allyl complex

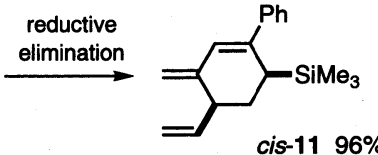

cis-11 96\%

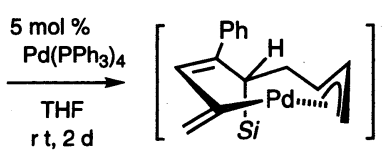

$12 \pi$-allyl complex

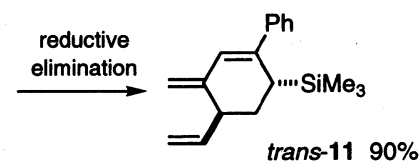

trans-11 $90 \%$
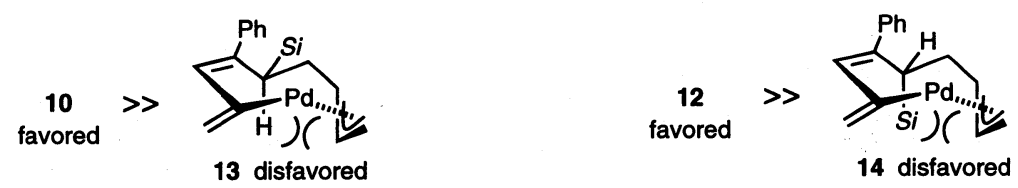
しても， 7 と同様な $\pi$ アリルパラジゥム錯体 $(10$ と 12) が中間に生成すると仮定することにより説明できる。こ の際, s-trans 型のブタジェンが異なる配向でパラジウ ムに配位してできる $\pi$ アリル錯体 13 は pseudoaxial ビ ニル基と pseudoaxial 水素, また 14 の場合は pseudoaxial ビニル基と pseudoaxial $\mathrm{SiMe}_{3}$ 基間の立体反発の ため不利となる。このように の生成は, 反応の推進力としてのみならず立体選択性の 発現にも重要な役割を果たしている。上記の高い立体特 異性は, エーテル基やカルボニル基などの配位性へテロ 原子官能基を持たない基質で得られている点であ特筆す べきものと言えよう。

\section{6. アレニルシクロプロパンの $[5+1]$ 付加環化反 応}

上記のように，ビニルアレンが遷移金属とメタラサイ クル性の強い錯体を形成することを利用して, 新しい $[4$ $+1]$ および $[4+2]$ 付加環化反応を開発することができ た。次に筆者らは，4炭素ユニットとして働くビニルア レンの代わりにアレニルシクロプロパンを用いれば，そ のホモログとして有用な 5 炭素ユニットとなるのではと 期待した。まず, 前述した $[4+1]$ 付加環化反応に做い, ロジゥム (I ) 触媒の存在下でアレニルシクロプロパンに 一酸化炭素を作用させて $[5+1]$ 付加環化反応を試みた。 しかし，アレニルシクロプロパンがメチレンシクロペン テンへ異性化するだけで14,15), カルボニル化は全く起こ らなかった。各種検討したところ, 中性イリジゥム ( I ) 錯体が優れたカルボニル化触媒であることがわかっ た ${ }^{16)}$ 。たとえば, Vaska 錯体の存在下で 15 に一酸化炭 素を作用させると， 6 員環生成物 (17) が $81 \%$ で生成す る。アレニル基が配位したイリジゥムに，近傍にあるシ クロプロパン環が酸化的付加し, 6 員環メタラサイクル
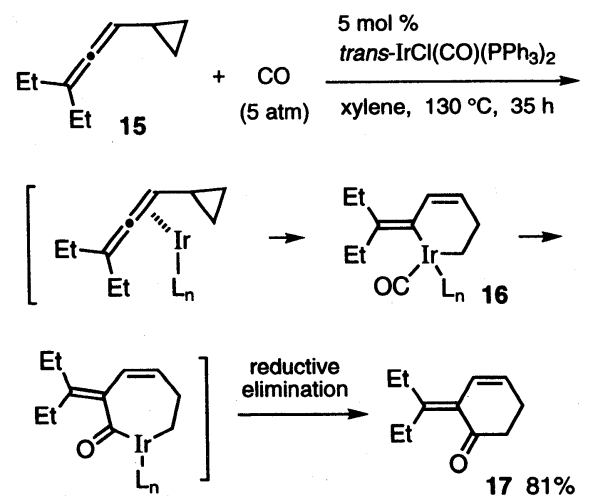

（16）を与える。さらに一酸化炭素が挿入した後に，シク ロヘキセノン誘導体が還元的脱離する。ロジゥム触媒の 場合は, 対応する 6 員環メタラサイクルが一酸化炭素の 挿入を待たずに直接還元的脱離を起こすすのと思われ る。

非対称なアレニル基を持つアレニルシクロプロパン （18）の場合，19 が立体選択的に得られ，環外二重結合に 関する立体異性体 20 の生成は認められなかった。アレ ニル基の立体的により空いた方向(メチル基側)からイリ ジゥムが近づいた結果と考えられる。
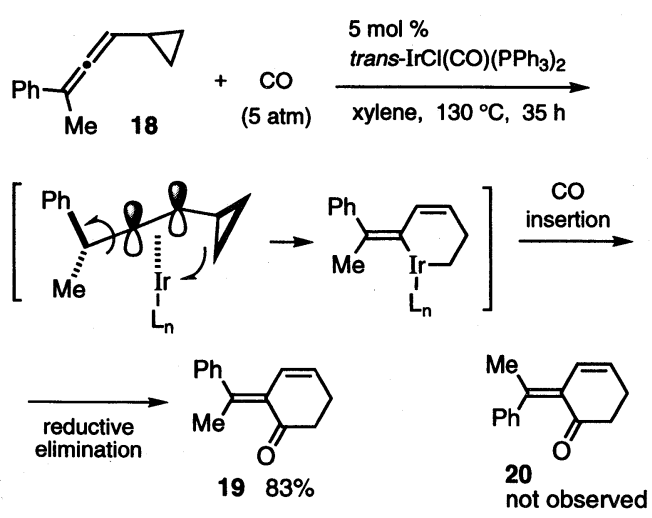

$[5+1]$ 付加環化反応は, 当量反応・触媒反応いずれに おいて屯例が少なく ${ }^{17)}$ ，またほとんどの場合芳香族化を 推進力としている。本反応は, 触媒反応でありしかも芳 香族化を伴わない初めての $[5+1]$ 付加環化反応の例であ る。また， ロジゥム触媒では困難な炭素一炭素結合生成 反応をイリジゥム触媒で達成している点 ${ }^{18)}$ で興味深い。

\section{7.おわりに}

以上，ビニルアレンー遷移金属錯体の構造に関する研 究に端を発した, 共役アレンの新しい付加環化反応の開 発について紹介した。アレン類は基本的な不飽和有機化 合物でありながら, 有機合成化学における注目度はオレ フィンやアセチレン化合物に較べてはるかに低かったよ うに思われる。著名な有機化学の教科書 ${ }^{19}$ にむ「Allenes are not generally encountered, because they are difficult to prepare and are relatively reactive.」とい う, 詋解を招く不適当な記述があるくらいである。本稿 で述べた反応例は，アレン類に潜在する合成素子として の広範な可能性の高さを示す一例と言えよう。

（平成 10 年 2 月 5 日受理） 


\section{文 献}

1) W. Carruthers, "Cycloaddition Reactions in Organic Synthesis", Pergamon, Oxford, 1990

2) M. Lautens, W. Klute, W. Tam, Chem. Rev., 96, 49 (1996)

3) (a) L.S. Trifonov, A.S. Orahovats, R. Trewo, H. Heimgartner, Helv. Chim. Acta, 71, 551 (1988); (b) S.P. Saberi, S.E. Thomas, J. Chem. Soc., Perkin Trans. 1, 1992, 259 ;(c) P. Areces, S. Jeganathan, W. H. Okamura, Anal. Quim., 89, 101 (1993); (d) M.S. Sigman, C.E. Kerr, B.E. Eaton, Organometallics, 14, 269 (1995)

4) M. Murakami, H. Amii, N. Takizawa, Y. Ito, Organometallics, 12, 4223 (1993)

5) (a) M. Murakami, K. Itami, Y. Ito, Angew. Chem., Int. Ed. Engl., 34, 2691 (1995);(b) idem, J. Am. Chem. Soc., 118, 11672 (1996)

6) (a) S. Otsuka, K. Tani, A. Nakamura, $J$. Chem. Soc. (A), 1969, 312;(b) T. Kashiwagi, N. Yasuoka, N. Kasai, M. Kukudo, J. Chem. Soc., Chem. Commun., 1969, 317

7) (a) J.W. Faller, A.M. Rosan, J. Am. Chem. Soc., 99, 4858 (1977); (b) B. Eaton, J.A., Jr., King, K.P. C. Vollhardt, ibid., 108, 1359 (1986); (c) G.M. Smith, H. Suzuki, D.C. Sonnenberger, V.W. Day, T.J. Marks, Organometallics, 5, 549 (1986)

8) (a) G.K. Barker, M.J.A. Green, K. Howard, J.L. Spencer, F.G.A. Stone, J. Chem. Soc., Dalton, 1978, 1839;(b) Y. Wakatsuki, K. Aoki, H. Yamazaki, ibid., 1986, 1193; (c) R. P. Hughes, P.R. Rose, A.L. Rheingold, Organometallics, 12, 3109 (1993);(d) T. Mitsudo, H. Watanabe, T. Sasaki, Y: Takegami, Y. Watanabe, K. Kafuku, K. Nakatsu, ibid., 8, 368 (1989); (e) M.A. Huffman, L.S. Liebeskind, ibid. , 11, 255 (1992)

9）ビニルアレンの $[4+1]$ 付加環化反応：(a) M.S. Sigman, B.E. Eaton, J. Am. Chem. Soc., 118, 11783 (1996); (b) T. Mandai, J. Tsuji, Y. Tsujiguchi, ibid., 115, 5865 (1993); (c) C. Darcel, C. Bruneau, P.H. Dixneuf, Synlett, 1996, 218

10) M.J. Burk, Y.M. Wang, J.R. Lee, J. Am.
Chem. Soc., 118, 5142 (1996)

11) M. Murakami, K. Itami, Y. Ito, J. Am. Chem. Soc., 119, 2950 (1997)

12) (a) H. tom Dieck, R. Diercks, Angew. Chem., Int. Ed. Engl., 22, 778 (1983); (b) I. Matsuda, M. Shibata, S. Sato, Y. Izumi, Tetrahedron Lett., 28, 3361 (1987); (c) S. Saito, M.M. Salter, V. Gevorgyan, N. Tsuboya, K. Tando, Y. Yamamoto, J. Am. Chem. Soc., 118, 3970 (1996); (d) V. Gevorgyan, A. Takeda, Y., Yamamoto, ibid., 119, 11313 (1997); (e) V. Gevorgyan, N. Sadayori, Y. Yamamoto, Tetrahedron Lett., 38, 8603 (1997)

13) M. Murakami, K. Itami, Y. Ito, J. Am. Chem. Soc., 119, 7163 (1997)

14）林実, 大松禎, 橋本幸彦, 西郷和彦, 日本化学会第 72 春季年会 $1 \mathrm{G} 129$ (1997)

15）同様な異性化は、ビニルシクロプロパンであよく 観察されている: (a) T. Hudlicky, "Comprehensive Organic Synthesis", Vol.8, eds. by B.M. Trost, I. Fleming, L.A. Paquette, Pergamon, Oxford, 1991, pp. 899-970 ; (b) R.I. Khusnutdinov, U.M. Dzhemilev, J. Organomet. Chem., 471, 1 (1994)

16) M. Murakami, K. Itami, M. Ubukata, I. Tsuji, Y. Ito, J. Org. Chem., 63, 4 (1998)

17) (a) S. Sarel, Acc. Chem. Res., 11, 204 (1978); (b) R. Aumann, J. Am. Chem. Soc., 96, 2631 (1974); (c) N.A. Grabowski, R.P. Hughes, B. S. Jaynes, A.L. Rheingold, J. Chem. Soc., Chem. Commun., 1986, 1694 ; (d) S.H. Cho, L. S. Liebeskind, J. Org. Chem., 52, 2631 (1987); (e) M.F. Semmelhack, S. Ho, M. Steigerwald, M.C. Lee, J. Am. Chem. Soc., 109, 4397 (1987);(f) Y. Owada, T. Matsuo, N. Iwasawa, Tetrahedron, 53, 11069 (1997)

18) (a) N. Chatani, S. Yamaguchi, Y. Fukumoto, S. Murai, Organometallics, 14, 4418 (1995); (b) R. Takeuchi, M.Kashio, Angew. Chem., Int. Ed. Engl., 36, 263 (1997); (c) J.P. Janssen, G. Helmchen, Tetrahedron Lett., 38, 8025 (1997)

19) S.H. Pine, J.B. Hendrickson, D. J. Cram, G. S. Hammond, "Organic Chemistry", 4th ed., McGraw-Hill, 1980, p.40 